\title{
PUDARNYA NILAI-NILAI PANCASILA DALAM KEHIDUPAN MASYARAKAT DI ERA GLOBALISASI
}

\author{
Ega Regiani \& Dinie Anggraeni Dewi \\ Universitas Pendidikan Indonesia \\ egaregiani@upi.edu
}

\begin{abstract}
Abstrak
Penelitian ini bertujuan untuk memberi gambaran akan bagaimana kondisi penerapan nilai-nilai pancasila di era gelobalisasi saat ini. Metode yang digunakan dalam penelitian ini yaitu menggunakan metode telaah pustaka. Pancasila sendiri merupakan pegangan untuk semua warga negara Indonesia dalam bertabiat serta berperangai. Dengan adanya pancasila, masyarakat Indonesia dapat memiliki pedoman dalam mengenali serta memecahkan suatu masalah yang berbau politik, sosial, budaya, hukum, dan lain-lain. Maka dari itu, nilai-nilai pancasila bagi masyarakat Indonesia dalam beraktivitas sangatlah penting. Pada era globalisasi ini, nilai-nilai pancasila mulai luntur. keadaan ini bisa diamati dari munculnya beragam macam masalah timbul karena tidak diaplikasikannya nilai-nilai dari pancasila, dan jika tidak segera diatasi mungkin bisa saja nilai-nilai dari pancasila atau makna pancasila itu sendiri akan lenyap.
\end{abstract}

Kata kunci: pancasila, nilai, globalisasi.

\begin{abstract}
This study aims to provide an overview of the conditions for the application of Pancasila values in the current globalization era. The method used in this research is using the literature review method. Pancasila itself is a guideline for all Indonesian people in behaving and behaving. With the existence of Pancasila, Indonesian people can have guidelines in recognizing and solving problems that are political, social, cultural, legal, and others. Therefore, Pancasila values in social life are very important. In this era of globalization, Pancasila values are starting to fade. This situation can be observed from the emergence of various kinds of problems arising from not applying the values of Pancasila, and if they are not immediately resolved, the values of Pancasila or the meaning of Pancasila itself may disappear.
\end{abstract}

Keywords: Pancasila, values, globalization.

\section{PENDAHULUAN}

Indonesia adalah salah satu Negara yang mempunyai histori dan asas ideologi yang digunakan dalam aktivitas berbangsa dan bernegaranya, berlainan dengan Negaranegara lain di dunia. Pancasila diangkat menjadi ideologi bangsa Indonesia dikarenakan, nilai-nilai yang tercantum di pancasila adalah nilai-nilai asli dari kepribadian bangsa Indonesia itu sendiri. Sebenarnya nilai-nilai yang tersemat pada pancasila diambil dari nilainilai luhur yang sudah berada serta berkembang pada setiap aktivitas masyarakat bangsa Indonesia bahkan saat Indonesia masih belum merdeka. Kemudian, nilai-nilai luhur tadi dicetuskan lagi oleh bapak pendiri bangsa ketika
Negara Indonesia didirikan sampai akhirnya dasar negara yang menjadi citacita bangsa Indonesia dirumuskan. Sesuai dengan yang telah dijelaskan Muzayin (1922) bahwa Pancasila itu merupakan paham dan karakter masyarakat Indonesia, dimana semua karakteristik nilai-nilainya sudah berperan secara nasional serta menjadi dasar peradaban bangsa, lalu bisa dikatakan jika nilai-nilai yang berada pada Pancasila tersebut ialah wujud dari pengaktualisasian atas cita-cita atau tujuan hidup bangsa Indonesia.

$$
\text { Nilai-nilai Pancasila mesti }
$$
ditumbuhkan sedari dini terhadap setiap masyarakat, penanaman sedari dini ini dapat dilakukan melalui pendidikan di tingkat dasar. Hal ini dilakukan karena, 
didalam nilai-nilai Pancasila ini tertera cita-cita bangsa Indonesia yang wajib untuk diangkat serta diupayakan. Nilainilai Pancasila harus ditanamkan sejak dini agar masyarakat Indonesia dapat menjalankan kehidupnnya dalam bermasyarakat dengan baik, apalagi Indonesia memiliki keanekaragaman suku, ras, agama, dan tingkat sosial.

Namun seiring bertambahnya zaman, nilai-nilai Pancasila mulai luntur dalam semua aktivitas yang dilakukan oleh setiap warga negara, ditambah kini memasuki era globalisasi, yang mana pada era ini ilmu pengetahuan serta teknologi berkembang pesat. Perkembangan teknologi di era globalisasi ini dapat mengikis nilai-nilai dari pancasila dalam bermasyarakat. Pada era globalisasi semua budaya maupun ideologi yang bersumber dari negara luar bisa masuk ke Indonesia dengan mudahnya.

Pudarnya nilai-nilai pancasila dalam kehidupan bermasyarakat dapat sangat berakibat bagi bangsa Indonesia, diantaranya mulai maraknya aksi tawuran yang dipicu oleh hal sepele. Kemudian terjadi kasus penistaan agama dan terjadi kejahatan-kejahatan yang mengatasnamakan agama seperti terorisme. Terorisme ini merupakan contoh akibat dari mulai pudarnya nilai-nilai pancasila sila pertama. Lalu maraknya terjadi pelecehan seksual, banyak terjadi korupsi, dan masih banyak lagi kasus-kasus lainnya.

Salah satu kasus yang terjadi karena mulai pudarnya penerapan nilai-nilai pancasila adalah aksi terorisme. Menurut Junaid (2013) terorisme merupakan sebuah pandangan yang meyakini jika penggunaan cara-cara kekerasan, ancaman atau sejenisnya yang dapat mengakibatkan kekhawatiran maupun kepanikan, hingga menimbulkan korban jiwa dan harta, aksi ini dilakukan demi meraih sebuah tujuan, yang dilakukan baik secara individu maupun berkelompok atau dalam sebuah organisasi, yang memiliki koneksi yang luas, baik bersekala nasional maupun internasional. Berdasarkan pengertian terorisme menurut Junaid tersebut, dapat dilihat bahwa aksi terorisme bukanlah hal yang dapat disepelekan. Aksi terorisme ini menyeleweng sekali dari beberapa nilainilai pancasila yaitu sila pertama, kedua, dan sila ketiga.

Telah terlihat jelas bagaimana kacaunya bangsa Indonesia jika nilai-nilai mulia yang tercantum pada Pancasila tidak kita implikasikan dalam kegiatan rutin kita. Maka dari itu, pengembalian nilai-nilai pancasila ini mesti segera dilakukan terhadap seluruh masyarakat Indonesia, terutama pada generasi muda Indonesia yang merupakan penerus serta pilar bangsa Indonesia.

\section{METODE PENELITIAN}

Penelitian ini sendiri dilakukan pada 13 April 2021. Target atau sasaran dari diadakannya penelitian ini yaitu seluruh warga Negara Indonesia.

Metode penelitian yang digunakan adalah dengan telaah pustaka yang berisi mengenai teori-teori yang memiliki keterkaitan dengan masalah yang sedang diteliti dalam penelitian ini. Dengan metode ini proses pengkajian menggunakan berbagai literatur yang berbeda mengenai konsep dan teori. Dengan menggunakan metode telaah pustaka ini masalah yang sedang diteliti oleh penulis dapat mudah untuk diselesaikan.

Sumber rujukan yang penulis gunakan untuk telaah pustaka adalah sumber-sumber penelitian yang telah ada sebelumnya, seperti berupa jurnal-jurnal ilmiah yang memiliki kaitannya dengan apa yang sedang penulis teliti saat ini dan hasilhasil penelitian lainnya. Selain itu penulis juga menelaah konsep atau teori-teori yang relevan dengan masalah ini. 


\section{HASIL PENELITIAN DAN PEMBAHASAN Hasil Penelitian}

Memudarnya nilai-nilai pancasila ini dapat kita perhatikan dari munculnya masalahmasalah yang bertentangan dengan Pancasila diantaranya, yang tidak sesuai dengan sila pertama yaitu terjadinya kasus penistaan agama, dan terjadinya kejahatankejahatan yang mengatasnamakan agama seperti aksi terorisme. Terjadinya perbudakan dan meperkerjakan anak dibawah umur serta terjadinya ketidakadilan pemerintah dalam memberi bantuan kepada orang yang membutuhkan tidak sesuai dengan sila kedua Pancasila. Terjadinya tawuran, perang antar suku serta banyak munculnya berbagai aliran sesat menjadi contoh perilaku yang tidak sesuai dengan sila ketiga. Untuk contoh tingkah laku yang tidak sesuai dengan nilai sila keempat yaitu, terjadinya ketidakadilan hukum, banyaknya kasus korupsi, dan masih banyak lagi kasus lainnya. Kemiskinan, maraknya perilaku diskriminasi atau perlakuan tidak adil karena hal tertentu adalah contoh perbuatan yang tidak sesuai dengan sila kelima Pancasila.

Contoh mulai pudarnya nilai-nilai pancasila dalam kehidupan masyarakat di era globalisasi yang mencolok yaitu tingginya tingkat kejahatan, keadaan ini bisa ditilik dari hasil penelitian yang diambil dari sumber databoks. Pada data tersebut dapat dilihat bahwa terdapat 336,652 kasus kejahatan yang dilaporkan kepolisian, angka ini turun dari tahun sebelumnya sebanyak 5,75\%. Turun juga tingkat resiko terkena kejahatan sebesar $7,86 \%$ jadi 129 jiwa per 100 ribu penduduk dari sebelumnya. Memang angka tersebut turun, namun sebenarnya kasus kejahatan masih banyak terjadi, hanya saja kasusunya tidak dilaporkan kepolisi. Untuk daerah dengan tingkat resiko kejahatan tertinggi di Indonesia terdapat di Polda Sulawesi Tengah dengan angka 345 jiwa per 100 ribu penduduk, dan tingkat resiko kejahatan terendah terdapat di Polda Jawa Tengah dengan angka 35 jiwa per 100 jiwa penduduk.

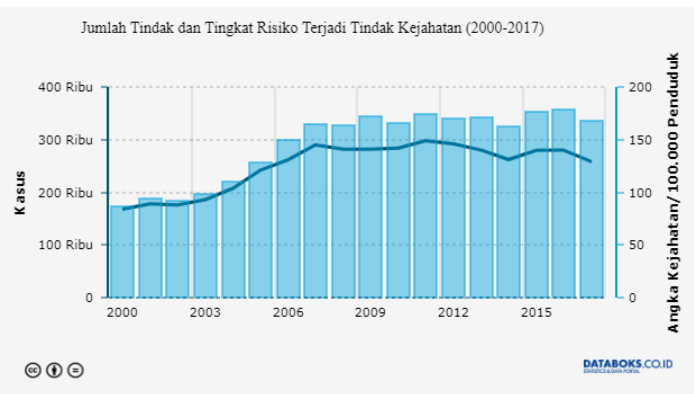

Gambar 1. Jumlah Tindak dan Tingkat Resiko Terjadi Tindak Kejahatan (200-2017)

Nilai-nilai Pancasila yang memudar juga dapat dilihat dari mulai menurunya rasa patriotisme dan nasionalisme dalam bangsa Indonesia terutama pada generasi muda. Pancasila kini kehilangan pamornya dikalangan generasi muda, sehingga nilainilai pancasila sudah kurang diaplikasikan dalam kehidupan sehari-hari. Generasi muda kini memandang budaya luar lebih modern dibandingkan dengan budaya sendiri. Padahal generasi muda sangat berperan penting dalam menjadi pilar bangsa Indonesia.

\section{Pembahasan}

Pancasila ialah dasar Negara serta pemikiran hidup bangsa Indoesia dalam berbangsa dan bernegara dan dijadikan pedoman atau patokan dalam mendirikan NKRI. Dasar Negara yaitu Pancasila tersebut direalisasikan pada hukumhukum Indonesia dengan menjadikannya sebagai induk dari semua hukum yang berlaku di Indonesia. Sementara itu, Pancasila selaku pemikiran hidup Indonesia digunakan untuk menjadi sebuah dasar untuk semua warga Indonesia dalam aktivitas rutin yang dijalaninya. Jadi dapat disimpulkan bahwa peranan pancasila adalah sebagai dasar untuk mengontrol keberjalanan ketatanegaraan Negara pada bagian 
ideologi, politik, sosial budaya, ekonomi, dan pertahanan keamanan.

Notonegoro memiliki pandangan mengenai Pancasila yang menurutnya Pancasila itu adalah dasar falsafah serta ideologi Negara Indonesia yang diimpikan akan dapat menjadi pegangan hidup bagi bangsa Indonesia menjadi pemersatu, simbol dari persatuan dan kesatuan serta sebagai pertahanan bangsa dan Negara Indonesia. Sedangkan menurut Ir. Soekarno pancasila bukan sekadar menjadi falsafah Negara saja, tapi lebih lapang lagi yaitu falsafah bangsa Indonesia. Berdasarakan kedua pendapat tersebut dapat disimpulkan bahwa pancasila adalah sebuah ideologi atau falsafah bangsa Indonesia yang ditujukan untuk menjadi pandangan hidup masyarakat Indonesia. Pancasila memiliki fungsi dan peranan secara umum yaitu:

\section{Pancasila Sebagai Jiwa Bangsa Indonesia}

Esensi fungsi pancasila selaku jiwa bangsa Indonesia yakni supaya Indonesia senantiasa ada pada jiwa Pancasila dimana ada lima sila yang jadi karakteristik unik bangsa Indonesia.

\section{Pancasila Sebagai Karakter Bangsa Indonesia}

Pancasila selaku karakter bangsa Indonesia memiliki arti yakni, Pancasila hadir beriringan dengan lahirnya Negara Indonesia dimana Pancasila ini mempunyai karakteristik unik dan hanya dipunyai bangsa Indonesia.

\section{Pancasila Sebagai Sumber dari Seluruh} Sumber Hukum

Pancasila selaku pusat dari seluruh sumber hukum berarti Pancasila mengendalikan seluruh hukum yang berjalan di Indonesia. Seluruh peraturan perundangan yang terdapat di Indonesia wajib bersumber serta tidak berlawanan dengan Pancasila. Pancasila itu tercantum dalam syarat paling tinggi ialah dalam Pembukaan UUD 1945 yang diuraikan lebih jauh dari UUD 1945 serta hukum positif yang lain.

\section{Pancasila Sebagai Perjanjian Luhur} PPKI (Panitia Persiapan Kemerdekaan Indonesia) selaku tubuh tempat perwakilan rakyat Indonesia pada bertepatan pada 18 Agustus 1945 menetapkan pembukaan serta batang badan UUD1945 yang berdasar pada Pancasila, sehingga bisa disimpulkan kalau Pancasila ini ialah ketentuan yaang terbentuk dari permufakatan bersama rakyat untuk selamanya.

\section{Pancasila Sebagai Cita- Cita serta} Tujuan Bangsa Indonesia

Cita- cita serta tujuan yang hendak digapai bangsa Indonesia ialah warga adil serta sejahtera yang menyeluruh secara materil serta spiritual yang bersumber pada Pancasila.

\section{Pancasila Sebagai falsafah Hidup Bangsa}

Pancasila merupakan falsafah hidup serta karakter Bangsa Indonesia yang memiliki nilai-nilai serta norma-norma yang oleh Bangsa Indonesia diyakini sangat benar, adil, bijaksana serta pas untuk Bangsa Indonesia buat mempersatukan Rakyat Indonesia.

Ideologi menjalankan tugas yang begitu penting saat melakukan operasi dalam memelihara kesatuan serta persatuan nasional, apalagi pada Negaranegara yang tengah berkembang layaknya pada negara Indonesia (Ubaidillah, 2000). Istilah ideologi sendiri berpangkal dari bahasa Yunani dari kata 'eidos' yang memiliki arti bentuk. Lalu ada kata 'idein' berarti melihat, dan 'logos' berarti ilmu. Kata idea sendiri berasal dari bahasa Sehingga dapat disimpulkan bahwa secara harfiah ideologi berarti pengertian- 
pengertian dasar, cita-cita yang memiliki sifat pasti yang harus dicapai, bersamaan dengan itu ideologi juga sebuah inti dasar, dan paham atau pendapat.

Sebagai pandangan hidup bangsa Indonesia, sebenarnya pada kenyataannya Pancasila bukan hanya sebuah ideologi yang terbentuk dari hasil dari gagasan ataupun pandangan seorang maupun kelompok seperti idelogi-ideologi di dunia pada umumnya, tetapi Pancasila merupakan sebuah ideologi yang nilainilai didalamnya diambil dari nilai-nilai tradisi, nilai budaya dan nilai keagamaan yang telah ada pada pemikiran setiap warga Indonesia jauh sebelum Negara Indonesia dibentuk, dengan demikian semua nilai-nilai dalam diambil dari pemikiran hidup warga Indonesia sendiri (Nurgiansah, 2021).

Pembukaan UUD Republik Indonesia tahun 1945 pada alinea keempat mengatur atau menunjukan kedudukan Pancasila sebagai ideologi bangsa dan Negara Indonesia. Berdasarkan hal tersebut sebagai ideologi bangsa, Pancasila harus dijadikan sebagai wawasan hidup, tujuan, kepercayaan, dan nilai luhur tersebut harus diaplikasikan ketika menjalankan aktivitas rutin. Selain memiliki fungsi umum, Pancasila juga memiliki fungsi pokok serta fungsi tambahan, yaitu sebagai berikut:

1. Fungsi pokok

Secara yuridis Pancasila menjadi dasar filsafat Negara ditemukan di Pembukaan UUD RI 1945 alinea empat, yang dapat dipketahui sebagai dasar filsafat Negara Indonesia. Pancasila sebagai dasar filsafat Negara memiliki makna yaitu bahwa Pancasila mengatur aspek penyelenggaraan Negara. Keterangan itu mencakup berbagai peraturan perundang-undangan pada Negara, budi pekerti, otoritas, warga, bangsa, wawasan nusantara, pemerintahan serta bagian-bagian kenegaraaan yang lain. Berkembang tidaknya suatu negara tergantung pada dasar filsafatnya, yang mana dasar filsafat ini menjadi sumber dasar nilai-nilai keabsahan, kebajikan, serta kesamarataan. Dengan menjadi dasar filsafat Indonesia, Pancasila menjadi sumber dari segala nilai-nilai luhur Indonesia. Kedudukan yang telah dijabarkan tadi, secara rinci bisa dinyatakan sebagai berikut :

a. Pancasila ialah sumber dari semua sumber hukum yang ada di Indonesia.

b. Pancasila mencakup suasana kebatinan yang berasal dari UUD tahun1945.

c. Pancasila membuat tujuan hukum bagi hukum dasar Negara Indonesia, yang tertulis maupun yang tidak tertulis.

d. Di dalam Pancasila terkandung aturan etika bagi pemerintahan dan semua pemelihara Negara, dengan maksud agar dapat mengkontrol sikap atau karakter manusia yang mulia serta mengikat dengan tetap tujuan budi pekerti masyarakat yang luhur.

\section{Fungsi tambahan}

Fungsi tambahan Selain memiliki fungsi pokok, Pancasila juga memiliki fungsi tambahan. Fungsi tambahan ini merupakan perwujudan dari fungsinya sebagai dasar Negara. Semua bidang baik itu bidang politik, ekonomi maupun bidang lainnya harus didasari oleh nilai-nilai Pancasila yang merupakan dasar Negara Indonesia, sehingga akan muncul fungsi serta kedudukan lain dari Pancasila selain menjadi dasar Negara. Berikut beberapa fungsi dan kedudukan Pancasila.

a. Sebagai pandangan hidup

Pancasila dalam kedudukannya sebagai pandangan hidup memiliki arti nilai-nilai Pancasila adalah patokan atau tuntunan bagi seluruh rakyat Indonesia dalam melakukan aktivitas rutinnya. Seluruh kegiatan yang dilakukan oleh masyarakat ataupun penyelenggara Negara mesti dijalankan serasi dengan nilai-nilai 
luhur Pancasila. Maka jika hal tersebut dijanalakan, cakupan Pancasila dalam fungsinya dalam menjadi pendirian hidup akan bertambah besar diaripada dalam fungsinya sebagai dasar Negara.

b. Sebagai jati diri bangsa

Penggagas Negara Republik Indonesia ketika sedang merumuskan dasar Negara berdasar atas sebuah pemikiran yang dimana mereka ingin membuat sebuah dasar Negara yang didalamnya mengandung makna hidup yang sesuai dengan karakteristik bangsa Indonesia. Makna hidup yang terkandung tersebut diangkat dari budayabudaya serta norma-norma masyarakat itu sendiri, yang merupakan sebuah pengaktualan dari nilai-nilai yang dikuasai, dipercayai, dan dihayati keaktualannya oleh warga Indonesia.

\section{c. Sebagai ideologi bangsa}

Pancasila sebagai Ideologi bangsa Indonesia memiliki arti yaitu bahwa, Pancasila adalah sebuah gagasan atau ideide yang sistematis serta keyakinan yang oleh bangsa Indonesia dijadikan sebagai patokan yang menyangkut dan mengatur tingkah laku dalam semua bidang kehidupan manusia. Bidang yang terliputi tersebut diantaranya, bidang politik, bidang sosial, bidang kebudayaan, dan bidang keagamaan.

Menurut Mulyana (2004) nilai merupakan sesuatu yang menjadi tujuan dari seseorang yang ketika hal itu terwujud, akan terwujud dalam bentuk tingkah laku ataupun sikap yang tertanam dalam setiap individu. Kaelan (2002) juga memberikan pendapatnya mengenai definisi nilai, yang menururtnya nilai itu sebenarnya merupakan suatu karakter yang terkandung dalam suatu objek. Pancasila ialah dasar Negara Indonesia yang tersemat didalamnya lima sila, kelima sila tersebut memiliki nilai-nilai penting dari setiap silanya.Berikut ini adalah penjabaran nilai-nilai dari setiap sila pancasila.

1. Sila Pertama "Ketuhanan Yang Maha Esa"

Nilai yang terukir pada sila pertama ini menyatakan masyarakat Indonesia diarahkan untuk dapat beritikad dan beriman terhadap Tuhan Yang Maha Esa. Pada sila ini juga memiliki nilai agar masyarakat Indonesia dapat memiliki sikap saling menghormati atau sikap toleransi antar pemeluk agama lain. Selain itu, sila ini menunjukan bahwa bangsa Indonesia dalam penyelenggaraan Negara, politik, pemerintahan, hukum serta peraturan perundang-undang Negara dijalankan menurut nilai Ketuhanan Yang Maha Esa.

2. Sila Kedua "Kemanusiaan Yang Adil dan Beradab"

Sila ini menunjukan agar Negara dapat mengangkat tinggi-tinggi derajat serta martabat seluruh manusia. Nilai yang terkandung pada sila ini yakni nilai kemanusiaan, yang dimana masyarakat Indonesia diharapkan dapat bersikap adil terhadap orang lain tanpa harus membedabedakannya. Disini juga masyarakat Indonesia ditekankan untuk memiliki sikap ramah dan saling menyayangi diri sendiri, dengan lingkungan, dan menyayangi antar sesama manusia.

\section{Sila Ketiga "Persatuan Indonesia"}

Pada sila ini terkandung nilai untuk dapat menunjukan rasa cinta tanah air atau nasionalismenya, serta dapat hidup dengan damai atau akur tanpa harus meributkan masalah mengenai beragam perbedaan yang ada seperti keragaman individu, suku, ras, golongan, kelompok, maupun perbedaan agama atau keyakinan, dan masyarakat Indonesia harus dapat meningkatkan diri dalam kesatuan dan persatuan. 
4. Sila Keempat "Kerakyatan Yang Dipimpin Oleh Hikmat Kebijaksanaan dalam Permusyawaratan Perwakilan"

Nilai yang terkandunya adalah masyarakat diharapkan dalam memecahkan suatu masalah dilakukan dengan melaksanakan kegiatan berunding serta menunjukan perilaku sama-sama menghormati pendapat. Pada sila ini, nilai kerakyatan mesti dijalankan oleh semua orang saat melakukan aktivitas berbangsa dan bernegara.

5. Sila Kelima "keadilan Sosial Bagi Seluruh Rakyat Indonesia"

Sila ini mengandung makna agar masyarakat dapat memiliki sikap peduli terhadap sesama, memiliki sikap empati, tidak hidup boros dan berlebihan, serta dapat mewujudkan keadilan social dengan selalu berusaha menunjukan diri melalui kerja keras.

Nilai-nilai pancasila sangat penting bagi warga Negara Indonesia ketika melakukan aktivitas sehari-hari. karena semua nilai yang tedapat pada Pancasila ialah nilai-nilai luhur yang mencirikan jati diri bangsa Indonesia. Pembukaan Undangundang Dasar tahun 1945 menunjukan Pancasila yang kedudukannya sebagai Ideologi Indonesia yang menjadi inti NKRI, dan semua itu harus dijalankan atau diaplikasikan dengan tetap pada aktivitas bermasyarakat, berbangsa dan bernegara.

Globalisasi ialah suatu fenomena unik yang terjadi pada peradaban manusia yang berjalan terus-menerus dalam masyarakat di seluruh dunia dan merupakan bagian dari proses manusia itu (Nurhaidah \& Musa, 2015). Berdasarakan pendapat ahli lainnya, globalisasi merupakan fenomena bermacam-macam yang mencakup bagian ekonomi, sosial, politik, teknologi dan budaya (Mir et al., 2014).

Faktor-faktor penyebab pudarnya nilai-nilai pancasila dalam kehidupan bermasyarakat di era globalisasi diantaranya, melonggarnya pegangan terhadap agama yang disebabkan oleh kemajuan zaman yang membuat segala sesuatu mudah dicapai dengan ilmu pengetahuan, sehingga keyakinan terhadap agama hanya sebagai simbol saja sementara perintah dan laranganlarangannya diabaikan. Selanjutnya, pembinaan moral yang dilakukan oleh pendidikan baik yang bersifat formal atau nonformal tidak berjalan dengan semestinya.

Rajasa (2007) berpendapat bahwa pengembang karakter nasionalisme bangsa Indonesia adalah para generasi muda yang melewati tiga proses, sebagai berikut:

1. Pembangun Karakter (character builder), para generasi muda memiliki peran dalam mewujudkan karakter positif bangsa dengan tekad yang kuat, demi mengangkat tinggi nilai budi pekerti serta mengaplikasikannya dalam semua kegiatan.

2. Pemberdaya Karakter (character enabler), yaitu generasi muda jadi panutan dalam pengembagan karakter positif, dengan cara berinisiatif untuk membangun pikiran yang kritis, misalnya saat menyuarakan tentang penuntasan masalah-masalah yang ada.

3. Perekayasa Karakter (character engineer), yaitu generasi muda memiliki peran dalam berprestasi baik itu ilmu pengetahuan maupun mengenai kultur bangsa Indonesia. Selain itu, generasi muda juga ikut terlibat dalam proses pembelajaran dengan tujuan untuk mengembangkan personalitas baik bangsa yang sejalan dengan sesuai dengan kemajuan dunia.

Berdasarkan uraian tersebut bisa dilihat jika generasi muda mempunyai tugas yang fundamental, dan nasib dari bangsa Indonesia yang akan datang 
bergantung pada sikap dan tindakan generasi muda. Menjunjung nilai-nilai pancasila ketika melakukan aktivitas rutin sangat penting untuk dilaksanakan. Oleh karena itu penumbuhan kembali nilai-nilai pancasila harus segera dilakukan.

Globalisasi tidak bisa dihindari oleh seluruh dunia terutama masyarakat Indonesia. Maka dari itu, upaya dalam rangka menumbuhkan kembali nilai-nilai Pancasila yang mulai terkikis oleh globalisasi perlu dilakukan. Cara yang dapat dilakukan untuk menumbuhkan kembali nilai-nilai Pancasila bisa diawali dengan melakukannya pada pendidikan yang ada di Indonesia, mulai dari tingkat Pendidikan Sekolah Dasar, Pendidikan Sekolah Menengah Atas hingga pada pendidikan tingkat Perguruan Tinggi. Penumbuhan kembali nilai-nilai Pancasila ini dimulai dari pendidikan karena, Pancasila sendiri memiliki kaitan yang kuat dengan pendidikan terutama Pendidikan Pancasila dan juga Kewarganegaraan PPKn.

Cara penumbuhan kembali nilai pancasila yang selanjutnya, dapat dilakukan dengan menanamkan rasa nasionalisme dan patriotisme kepada setiap warga Negara. Rasa nasionalisme dan patriotisme dapat dipupuk kembali dengan cara mengikuti atau berpartisipasi dalam kegiatan-kegiatan yang berbau nasional seperti ketika memperingatan hari kebangkitan nasional, hari kemerdekaan Indonesia, hari lahirnya pancasila dan lain sebagainya.

Bagi pelajar, mereka bisa menumbuhkan rasa nasionalismenya dengan cara belajar dengan serius, semangat dan gigih dengan tujuan untuk menjaga nama baik bangsa Indonesia, mencintai dan senang dalam memakai produk-produk lokal sehingga perekonomian Indonesiapun akan maju. Bukan hanya dengan cara sepeti itu saja, namun juga dengan membuat sebuah karya seni seperti dalam bidang seni musik baik itu berupa musiknya maupun seni vokalnya, lukisan, seni peran atau teater dan karya-karya lainnya yang memiliki tema cinta tanah air juga merupakan suatu bentuk dalam memupuk kembali rasa nasionalisme maupun patriotisme kita selaku bangsa Indonesia.

\section{KESIMPULAN}

Pancasila diresmikan menjadi dasar Negara Indonesia yang berupa ideologi atau citacita, paham, serta pegangan hidup yang wajib digunakan sebagai pandangan dalam bermasyarakat oleh rakyat Indonesia. Nilai-nilai pancasila sangat penting bagi bangsa Indonesia, karena dengan nilai-nilai pancasila inilah masyarakat Indonesia dapat bersikap serta bertindak sesuai dengan karakter bangsa Indonesia itu sendiri. Namun pada era globalisasi ini, nilai-nilai pancasila sudah mulai pudar, sehingga menyebabkan munculnya berbagai masalah. Untuk itu diperlukan sebuah usaha yang dilakukan untuk menumbuhan kembali nilai-nilai luhur pancasila.

Kita sebagai warga Negara Indonesia memiliki sebuah ideologi atau patokan dalam melakukan kegiatan bermasyarakat, berbangsa dan bernegara yaitu pancasila. Oleh karena itu, nilai-nilai dari pancasila jangan sampai luntur atau redup, terutama dalam era globalisasi ini. Karena dengan pancasila lah jati diri kita sebagai bangsa Indonesia tidak akan hilang. Hal yang dapat kita lakukan agar nilai-nilai Pancasila yang sudah pudar ini tumbuh kembali dalam kehidupan kita yaitu dengan cara, menanamkan serta menjalankan ajaran agamanya dengan baik, lalu kita dapat menanamkan serta mewujudkan nilai pancasila dengan baik, menegakkan supremasi hukum, serta selektif dalam pengaruh globalisasi baik itu dari sektor politik, ideologi, ekonomi, sosial budaya bangsa juga merupakan cara-cara yang dapat kita lakukan untuk menumbuhkan 
kembali nilai-nilai luhur pancasila dalam kehidupan kita.

Bagi pelajar, mereka bisa menumbuhkan rasa nasionalismenya dengan cara belajar dengan serius, semangat dan gigih dengan tujuan untuk menjaga nama baik bangsa Indonesia, mencintai dan senang dalam memakai produk-produk lokal sehingga perekonomian Indonesia pun akan maju.

\section{DAFTAR PUSTAKA}

Anggraini, D., Fathari, F., Anggara, J. W., \& Amin, M. D. A. A. (2020). Pengamalan Nilai-nilai Pancasila Bagi Generasi Milenial. Jurnal Inovasi Ilmu Sosial dan Politik. 2(1). 11-18.

Arfyand, A. I. (2018). Internalisasi Nilai-Nilai Pancasila Melalui Pusat Studi Pancasila Sebagai Upaya Penguatan Ideology Bangsa Bagi Generasi Muda. Untirta Civic Journal. 3(2). 158167.

Atikarini, D. (03/12/2018). Penyimpangan Nilai-nilai Pancasila Yang Terjadi di Indonesia. Retrieved 27 March, 2021, from https://osf.io/preprints/inarxiv/vjc3u/

Asmaroini, A. P. (2016). Implementasi Nilai-Nilai Pancasila Bagi Siswa Di Era Globalisasi. Jurnal Pancasila dan Kewarganegaraan. 4(2). 440-450.

Asrori, A., Bakhita, F., \& Aulia, R. (2019). Lunturnya Norma Pancasila Di Era Milenial 2019/2020. Jurnal Ilmiah Profesi Pendidikan. 4(2). 83-90.

Badan Pusat Statistik. (2018). Sepanjang 2017 Terjadi 337 Ribu Tindak Kejahatan di Indonesia. Retrieved $13 \quad$ April, 2021, from https://databoks.katadata.co.id/datapublish/2019/07/22/sepanjang-2017-terjadi-337ribu-tindak-kejahatan-di-indonesia

Gesmi, I., Hendri,Y. (2018). Buku Ajar Pendidikan Pancasila. Sidoarjo: Uwais Inspirasi Indonesia.

Graciella, L.O. (01/2019). Kedudukan Dan Fungsi Pancasila Bagi Bangsa Dan Negara Indonesia. Retrieved $27 \quad$ March, 2021, from https://www.researchgate.net/publication/330278797_Kedudukan_dan_Fungsi_Pancas ila_bagi_Bangsa_dan_Negara_Indonesia

Hidayatillah, Y. (2014). Urgensi Eksistensi Pancasila di Era Globalisasi (Studi Kritis Terhadap Persepsi Mahasiswa STKIP PGRI Sumenep tentang Eksistensi Pancasila). Jurnal. 6(2).

Junaid, H. (2013). Pergerakan Kelompok Terorisme Dalam Perspektif Barat Dan Islam. Jurnal sulesna. 8(2). 118-135.

Kristiono, N. ( 2017). Penguatan Ideologi Pancasila Di Kalangan Mahasiswa Universitas Negeri Semarang. Harmony:Jurnal Pembelajaran IPS dan PKN. 2(2). 193-204.

Maryono. (2018, 02 Juni). Peran Mata Kuliah Pendidikan Kewarganegaraan Dalam Mengatasi Pudarnya Nilai-nilai Luhur Pancasila Generasi Zaman Now. Prosiding Seminar Nasional PPKn 2018. Retrieved 27 March, 2021, from https://ppkn.fkip.uns.ac.id/wpcontent/uploads/2018/08/Maryono.-STKIP-PGRI-PACITAN..pdf

Mulyana, R. (2004). Mengartikulasikan Pendidikan Nilai. Bandung: Alfabeta.

Muzayin. (1992). Ideologi Pancasila (bimbingan Ke Arah Penghyatan dan Pengamalan bagi Remja). Jakarta: Golden Terayon Press.

Nurhaidah, \& Musa, M, I.(2015). Dampak Pengaruh Globalisasi Bagi Kehidupan Bangsa Indonesia. Jurnal Pesona Dasar. 3(3). 1-14.

Nurgiansah, T. H. (2021). Pendidikan Pancasila. In Solok: CV Mitra Cendekia Media.

Octavian, W. A. (2019). Upaya Peningkatan Pemahaman Nilai Pancasila Terhadap Siswa Melalui Kegiatan Penyuluhan. Jurnal Bhineka Tunggal Ika. 6(2). 199-207. 